\title{
Estimation of Rat Brain Acetylcholine I. Effect of Time Lapse Between Killing and Freezing of the Brain
}

Estimation of acetylcholine (ACh) in the brain tissue has been a point of discussion for all these years. While various methods of the estimation of $\mathrm{ACh}$ have been in use $^{1-7}$, and also the procedures of the isolation and treatment of tissue, none of the methods used in the isolation of brain tissue seems satisfactory. Rapid breakdown of ACh during the removal of the tissue and the time required between killing, removal and cleaning of the brain and treatment for extraction of ACh seems one of the main causes of the discrepancy observed in the results reported. by various workers $4,5,8,9$.

It would therefore, be desirable to determine whether these differences in $\mathrm{ACh}$ levels are indeed due to changes in ACh content of the brain that have arisen during the isolation procedure or do, in fact, represent actual $\mathrm{ACh}$ levels in the brain.

Results of one aspect of the study to determine whether rapid freezing of the head to freeze the brain immediately after decapitation would in fact result in better recoveries of $\mathrm{ACh}$ and the effect of time gap between killing and freezing of the tissue before extraction of $\mathrm{ACh}$, are reported in this communication.

Methods and materials. Male wistar rats (300-400 g) were used in the study. The rats were killed by decapitation and the heads were dropped into a bath of liquid nitrogen for freezing at different time intervals after decapitation. Brains from the frozen heads were later removed in ice $\left(0-4^{\circ} \mathrm{C}\right)$ and homogenized immediately in ice-cold TCA $(5 \%, w / v)$. ACh was isolated from the TCA extract of the whole brain according to the method

Table I. Concentrations of acetylcholine in brain of rats frozen in liquid nitrogen at different time

\begin{tabular}{rll} 
& & Acetylcholine Levels \\
\cline { 2 - 3 } $\begin{array}{l}\text { Time passed before the } \\
\text { decapitated head was dropped } \\
\text { into liquid } \mathrm{N}_{2} \text { (sec) }\end{array}$ & $\begin{array}{l}\text { Concentration } \\
\text { (nmole/g fresh } \\
\text { weight of brain) }\end{array}$ & Recovery (\%) \\
\hline 0 & & \\
\hline 2 & $34.65 \pm 3.15$ & $(100)$ \\
5 & $34.65 \pm 3.15$ & 100 \\
10 & $34.65 \pm 3.15$ & 100 \\
15 & $32.55 \pm 2.10$ & 93.9 \\
30 & $28.35 \pm 3.15$ & 81.8 \\
60 & $24.15 \pm 2.70$ & 69.7 \\
120 & $17.85 \pm 2.10$ & 51.5 \\
\hline
\end{tabular}

The results are the means \pm S.E. of 6 experiments at each time point.

Table II. Comparison of acetylcholine levels in rat brain

\begin{tabular}{lll}
\hline $\begin{array}{l}\text { Acetylcholine } \\
\text { concentration } \\
\text { (nmole/g fresh weight) }\end{array}$ & Reference \\
\hline & 14.6 & STAvinoHA and RYAN $^{8}$ \\
& 21.0 & STAviNoHA and RYAN $^{8}$ \\
& 12.4 & FEILMAN \\
& 13.9 & PotTER \\
& 34.65 & This paper \\
$0 \min$ & 13.65 & This paper
\end{tabular}

described by NaKamura et al. ${ }^{10}$. ACh fractions obtained on elution from BioRex-70+ column with $15 \mathrm{~m} M$ formic acid as eluant were pooled, freeze-dried and kept frozen before analysis. In control experiments, the recovery of ACh was found to be better than $93 \pm 3 \%$, where a known amount of ACh was added to the TCA extract before isolation of $\mathrm{ACh}$. The amounts of $\mathrm{ACh}$ in the freezedried samples were assayed with the frog rectus abdominis muscle?

Results and discussion. The concentration of $\mathrm{ACh}$ in the brains from rats killed and the heads dropped in liquid nitrogen for freezing at different time intervals are presented in Table I. While the level of ACh was unaffected up to a time lapse of $5 \mathrm{sec}$ between the killing and freezing of the brain, about $50 \%$ of the total $\mathrm{ACh}$ was lost, if the time gap was $60 \mathrm{sec}$.

The values of ACh obtained in these experiments at 0 min and after a lapse of 2 min between killing and freezing of the tissue are compared with those already reported in the literature in Table II. While all the reported values are almost one third of the 0 min levels of ACh obtained in this experiment, it is of interest to note that 2 min levels in this experiment correspond exceedingly well with the reported values for $\mathrm{ACh}$ in brain.

It appears, therefore, that the time between the killing of the animal and the freezing of the head is of extreme importance. Even a delay of $30 \mathrm{sec}$ causes a decresae in ACh level (up to 30\%) and, therefore, extreme caution in obtaining tissue must be taken before any meaningful interpretation of the results obtained can be undertaken.

These results, in part, could possibly explain the wide range of $\mathrm{ACh}$ levels reported for rat brain tissue by various workers in the field. It is suggested that in determining the levels of $\mathrm{ACh}$ in whole brain or parts of the brain, the samples must be frozen within $10-15 \mathrm{sec}$ after killing the animal to avoid excessive losses in its concentration.

Zusammenfassung. Es wird nachgewiesen, dass die Zeitspanne, die für die Extraktion von Acetylcholin gebraucht wird, auf seine quantitative Bestimmung entscheidend ist.

S. Kumar

Department of Pediatrics, Methodist Hospital, 506 Sixth Street, Brooklyn (New York 11215, USA), 25 August 1972.

1 J. R. Steinhart, Biochim. biophys. Acta 158, 171 (1968).

2 H. Jasper and I. Koyama, Can. J. Physiol. Pharmac. 46, 692 (1968).

3 D. E. Schmint, P. I. A. Szilagyi, D. L. Alkon and J. P. Green, J. Pharmac. exp. Ther. 174, 337 (1970).

4 V. P. WhitTaker, in Handbuch der Expevimentellar Pharmakologie Ergänzungwerk (Ed. G. B. KoELLE; Springer-Verlag, Berlin 1963), vol. 15, p. 1.

5 W. D. Reid, D. R. Haubrich and G. Krishna, Analyt. Biochem. 42,390 (1971).

6 J. J. O'Neill and T. Sakamoto, J. Neurochem. 17, 1451 (1970).

7 C. H. ChANG and J. H. GADDUM, J. Physiol., Lond. 79, 255 (1933).

${ }^{8}$ W. B. Stavinoha and L. C. Rayn, J. Pharmac. exp. Ther. 150, 231 (1965).

9 J. H. Feldman, J. Neurochem. 16, 135 (1969).

10 R. Nakamura, S. C. Cheng and H. Naruse, Biochem. J. 120, 345 (1970).

11 L. T. Porter, in Handbook of Nenrochemistry (Ed. A. LAJTHA; Plenum Press, New York 1970), vol. IV, p. 263. 